\title{
Nature as an Ideal Rhythm Model for Optimal Cardiovascular Physiology and Health
}

\author{
Editorial
}

Akbar Nikkhah

Chief Highly Distinguished Professor, Department of Animal Sciences, Faculty of Agricultural Sciences, University of Zanjan, Principal Highly Distinguished Scientist, National Elite Foundation, Iran.

\begin{abstract}
This article innovatively describes nature as an ultimate rhythm model for optimizing human physiology and health. Circadian rhythms of biological systems orchestrate cell metabolism and survivorship for reasonable longevity and health. Establishing optimal circadian rhythms of life affairs of mainly eating, resting and exercising will better coordinate metabolic interactions among different tissues. As a result, cardiovascular energetic and waste management could significantly improve.
\end{abstract}

Keywords: Nature; Rhythm; Model; Cardiovascular System; Physiology.

\section{*Corresponding Author:}

Akbar Nikkhah,

Chief Highly Distinguished Professor, Department of Animal Sciences, Faculty of Agricultural Sciences, University of Zanjan, Principal Highly Distinguished Scientist, National Elite Foundation, Iran.

Email:anikkha@yahoo.com

Received: April 29, 2015

Published: May 04, 2015

Citation: Akbar Nikkhah (2015) Nature as an Ideal Rhythm Model for Optimal Cardiovascular Physiology and Health. Int J Diabetol Vasc Dis Res, 3(2e) 1-2. doi: http://dx.doi.org/10.19070/2328-353X-150009e

Copyright: Akbar Nikkhah ${ }^{\circ}$ 2015. This is an open-access article distributed under the terms of the Creative Commons Attribution License, which permits unrestricted use, distribution and reproduction in any medium, provided the original author and source are credited.

\section{Science Description and Innovation}

Nature functions on a circadian cycle that equals to almost a 24-h period [1]. This means that any biological system in nature must develop and possess such circadian rhythmicity in its physiological foundation to be able to survive. Apart from evolution, mammals including humans in most parts of the world live within circadian life patterns that regulate their physiology healthfully. The phenomenon of modernity, however, has in many ways interfered with such a natural rhythmicity of human physiology. Altered and in many cases entirely or partially shifted times of eating, sleeping, physical activity, socializing, travelling and all related life tasks have led to altered physiological responses from cells and tissues to environmental cues. This consequence must have contributed to the emergence and increased incidence of many complicated diseases and syndromes such as cancer and brain-nervous-immune abnormalities in modern humans.
Cardiovascular complexities and deficiencies as major causes of morbidity and mortality worldwide could increasingly occur due to asynchronies in circadian patterns of eating, resting and exercising [2-4]. Irregular daily patterns of eating and resting rate and extent alongside no time allowance for adequately intense physical activity immensely impair normal cardiovascular function. It has recently been criticized that defining weekly minimums of exercise time and intensity are greatly insufficient and unrepresentative in meeting cardiovascular requirements of metabolic turnover and waste drainage and management $[4,5]$. In other words, regularities in conducting adequate exercise and low-stress social interactions complemented with timely and frequent-and-light eating meals must be established on a circadian basis and not in longer intervals [6-8]. This guarantees that cell physiology abides by natural laws in maintaining optimal nutrient intake behaviour, metabolic and oxidation rate, and waste managing. The consequence is a healthy life with minimal life physiological tolls $[9,10]$.

\section{Implications}

This article established a novel ideology that directs human physiology down from genes and their components up to organs and the whole body to accord with natural rhythms of especially circadian properties. Eating, sleeping, resting, exercising, socializing, travelling, and related life affairs must be coordinated within a rhythmic circadian framework for the cardiovascular system to function optimally with reasonable longevity.

\section{Acknowledgment}

Thanks to Iran's Ministry of Science Research and Technology, National Elite Foundation, and University of Zanjan for supporting the author's global programs of optimizing science edification in the third millennium. 


\section{References}

[1]. Nikkhah A (2012) Time of Feeding an Evolutionary Science, Lap Lambert Publishing, GmbH \& Co. KG, Germany 192, ISBN 978-3-8473-3260-2.

[2]. Nikkhah A (2014) Eating timing and diabetes. Int.J. Diabetol. Vas. Dis. Res 2: 101.

[3]. Nikkhah A (2015) Intake circadian physiology: An overlooked public health concern. Endocrinol. Metab. Synd 1:1.

[4]. Nikkhah A (2015) Optimizing health management through circadian feed intake rhythms: A prognostic SciTech. J. Vet. Sci. Technol 6: 115.

[5]. la Fleur SE, Kalsbeek A, Wortel J, Fekkes MI, Buijs RM (2001) A daily rhythm in glucose tolerance: a role for the suprachiasmatic nucleus. Diabetes 50: $1237-1243$.
[6]. Nikkhah A (2015) Creating rhythmic regularities in cell physiology: A novel global program to prevent cancer. AusJ. Nutr. Health Food Eng. In Press.

[7]. Nikkhah A (2015) Wrecked oncogenesis through synchronized substrate availability and oxidation: A novel bioengineering of cell physiology. Aust. J. Biotechnol. Bioeng. In Press.

[8]. Nikkhah A (2014) When to eat to beat obesity and diabetes? J. Diabet. Metab 5:7

[9]. Nikkhah A (2015) Harmonizing Eating and Exercise Circadian Rhythms for Optimal Glucose-Insulin and Vascular Physiology. Int. J. Diabetol. Vasc. Dis. Res. Int J Diabetol Vasc Dis Res 3(3): 87-88.

[10]. Nikkhah A (2015) Breast Health Progress through Exercise-Driven Lactation: A Pragmatic Bioprocess to Prevent Cancer. J. Bioprocess. Biotechniq 5:3, e127. 